\title{
Dialógos entre saberes (LEFF, E. Epistemologia ambiental. São Paulo: Cortez, 2001)
}

\section{Dealing with different knowledge aspects (LEFF, E. Epistemologia ambiental. São Paulo: Cortez, 2001)}

\author{
Lúcia Helena de Oliveira CUNHA*
}

A leitura de Epistemologia ambiental, de Enrique Leff, convida-nos a várias reflexões, diante da riqueza e densidade de questões que o autor aborda, neste contexto de crise socioambiental que marca as sociedades contemporâneas. Tais questões abrangem desde a articulação entre os distintos campos do conhecimento para apreensão da dinâmica sociedade-natureza, o processo de transformação do conhecimento até a construção do saber e da complexidade ambiental e o significado de uma nova racionalidade ambiental. Como observa Floriani (2001), ${ }^{1}$ outras questões relevantes, de ordem epistemológica e política são tematizadas no interior da obra, as quais exigiriam um debruçar mais detido para apreendê-las em profundidade.

Parece perpassar esses temas, no entanto, a preocupação constante do autor em proceder à desconstrução do pensamento unitário, disciplinar, instrumental e reducionista que rege a lógica ocidental dominante - com nítidos reflexos no pensamento científico e filosófico-, em especial na forma de conceber o mundo natural e social. Propondo-se romper com perspectivas lineares, fragmentárias, coisificadoras e unidimensionais, calcadas em estruturas totalitárias, Leff preconiza um novo modelo de conhecimento, no qual a razão aberta, crítica e criativa, livre de certezas insustentáveis, faz-se presente.

Transpondo a ambientalização do conhecimento - que apenas toma o ambiental uma dimensão do real -, o autor assinala a importância da construção de um saber ambiental amplo, comprometido não somente com as formas de objetivação do ser (e do conhecer), mas com a apropriação subjetiva da realidade, imprimindo novos sentidos civilizatórios ao mundo -, com o forjar de novas teorias, ideologias e utopias (novas ações sociais), para a reapropriação da natureza e novos relacionamentos entre os homens.

A preocupação de Leff no campo epistêmico é rediscutir os nexos entre realidade e conhecimento, entre teoria e práxis, entre objetividade e subjetividade, entre ser e conhecer, entre saber formal e saberes patrimoniais, rompendo com as dicotomias tão características da ciência moderna dominante; no plano político, a proposta do autor é a de integrar esses pares aparentemente opostos, excludentes, em saberes geradores de uma nova utopia, de novas solidariedades e sentidos - de uma ordem social e ambiental. Dessa perspectiva, esse processo implica "a aventura na construção de novos sentidos do ser", onde o inédito tem lugar.

Devido à amplitude e multiplicidade de questões abrangidas em Epistemologia ambiental, fixo-me, aqui, em uma das proposições do autor que julgo revolucionária, do ponto de vista do conhecimento e da ação social: a idéia de que a construção de novos paradigmas envolve um amplo diálogo entre tradição e modernidade, ou seja, toma-se como pressuposto que uma nova relação entre o homem e a natureza, num intercruzamento entre várias temporalidades, implica um olhar sábio e simultâneo para frente e para trás. $\mathrm{Ou}$, em outros termos, em seu projeto teórico-político, o autor propõe a busca de novas trilhas no fluxo da história, onde a tradição possa ser ressignificada.

\footnotetext{
* Lúcia Helena de Oliveira Cunha é antropóloga, professora aposentada da Universidade Federal da Paraíba e colaboradora do NUPAUB-USP.

1 Ver, nesta revista, a resenha de Dimas Floriani sobre o mesmo livro, na qual procede a uma análise interna detalhada da obra de Leff, assinalando as contribuições que traz para o conhecimento, principalmente, sobre como tal pensador trata, contemporaneamente, dos desafios da complexidade ambiental.
} 
No plano epistêmico, isso requer um esforço de ruptura não somente com os abismos historicamente produzidos entre as distintas áreas do conhecimento (sem com isso implicar dissolução das áreas constituídas), mas um diálogo fecundo com outras expressões do saber e cosmovisões, tecidas ao longo do tempo para a produção e recriação da vida em sua diversidade e múltiplas dimensões.

A originalidade da proposta de Leff está em reconhecer o valor e o estatuto de saberes milenares ou seculares na construção de um novo modelo de conhecimento, propondo uma dialogia com os sujeitos e a ciência da tradição ou com saberes organizados pela cultura - num movimento contínuo de atualização e renovação -, em que há convivênvia e confluência entre modos de vida, com expressões identitárias compartidas. Nesses termos, e acentuando a dimensão política de seu projeto, assim afirma o autor:

...o diálogo de saberes na gestão ambiental, num regime democrático, implica a participação das pessoas no processo de produção de suas condições de existência. Por isso é o encontro entre a vida e o conhecimento, a confluência de identidades e saberes. A encruzilhada pela sustentabilidade é uma disputa pela natureza e uma controvérsia pelos sentidos alternativos do desenvolvimento sustentável. Isso faz com que a sustentabilidade tenha como condição iniludível a participação de atores locais, de sociedades rurais e comunidades indígenas, a partir de suas culturas, seus saberes e suas identidades.

O caráter inovador da proposta de Leff repousa, pois, no fato de ultrapassar a perspectiva academicista, disciplinar e auto-referente da ciência moderna, que elege a si própria como forma única, superior e absoluta do conhecimento - a medida de todas as coisas -, negando ou ossificando outras expressões culturais do saber, dotadas de lógicas distintas. É nesse sentido que o diálogo entre saberes deve abranger o entrelaçamento ou complementaridade de prismas diferenciados, assim como o elo entre tempos, no qual saberes seculares e milenares imbuídos de pensamento cosmogônico e histórico permitam num intercâmbio com outros saberes e identidades, novas formas de apropriação do mundo (e da natureza).

O saber ambiental fundado no encontro (confronto) de múltiplos saberes, legitimados por diferentes matrizes de racionalidades inscritas em lógicas culturais distintas, deve propiciar a produção de novas categorias e estratégias conceituais, não constituindo um campo discursivo homogêneo estabelecido a priori: ao contrário, é um campo que se constrói continuamente em relação com o objeto, com o sujeito e com o tema de cada área do conhecimento, em suas articulações com as demais áreas.

Sem incorrer em ecletismos epistemológicos, vale ressaltar que o saber ambiental, para Leff, envolve paradigmas de conhecimentos de diversas ordens, os quais abrangem, também, sistemas de valores, crenças, técnicas e práticas produtivas referentes à vida material, social e natural e à apropriação e produção do ambiente, orientados por princípios de sustentabilidade, ou seja, nas palavras do autor, esse saber não apenas gera um conhecimento científico mais objetivo, abrangente, mas também produz novas significações sociais, novas formas de subjetividade e de posicionamento ante o mundo. Sob esse olhar, Leff propugna a ampliação de perspectivas e o alargamento de horizontes para o conjunto da produção humana em sua diversidade.

Tal diversidade se manifesta tanto na constituição interna do campo científico, nas formas de organização dos saberes culturais, em suas múltiplas expressões - materiais e simbólicas -, como na manifestação dos sentidos do ser. O reconhecimento do diverso nos modos de ser, pensar e conhecer, ou de um saber ser com a outridade, permeia a obra de Leff, integrando sua proposta de constituição de um novo saber e racionalidade ambiental - de hibridização das ciências, de intercâmbio cultural e de um circuito dialógico entre tempos e saberes. Importante em sua proposta é que conhecer e ser configuram-se como dimensões conectadas - formam unidades indissociáveis. Por isso, o vir a ser, na construção de futuros inéditos, congrega saberes e tempos diversos, em relação de coetaneidade, e emerge sempre como possibilidade(s) do ato do conhecer, do conceber, do fazer e dos sentidos imputados ao mundo. 